\title{
$\beta$-Catenin Cooperates with CREB Binding Protein to Promote the Growth of Tumor Cells
}

\author{
Wendan Yu ${ }^{a}$ Liren $\mathrm{Li}^{\mathrm{b}} \quad$ Fufu Zheng ${ }^{\mathrm{c}}$ Wenjing Yang ${ }^{\mathrm{a}}$ Shilei Zhao \\ Chunfang Tian ${ }^{\mathrm{a}}$ Wenwen Yin ${ }^{\mathrm{a}}$ Yiming Chen ${ }^{\mathrm{a}}$ Wei Guo ${ }^{\mathrm{a}}$ Lijuan Zou $^{\mathrm{a}}$ \\ Wuguo Denga, b
}

Institute of Cancer Stem Cell \& The Second Affiliated Hospital, Dalian Medical University, Dalian, bSun Yat-sen University Cancer Center, State Key Laboratory of Oncology in South China, Collaborative Innovation Center of Cancer Medicine, Guangzhou, The First Affiliated Hospital of Sun Yat-sen University, Guangzhou, China

\section{Key Words \\ $\beta$-catenin $• \mathrm{CBP} \cdot$ Lung cancer $•$ Prognosis}

\begin{abstract}
Background/Aims: $\beta$-catenin is an integral component of the canonical Wnt signaling pathway, and its mutations are an autosomal recessive cause of colorectal cancer (CRC), medulloblastoma (MDB), and ovarian cancer. Nevertheless, little is known about its function in lung cancers. Methods: We first knocked down $\beta$-catenin by siRNA to investigate its effects on lung cancer cell proliferation, migration and apoptosis. Then we verified the interaction between $\beta$-catenin and CREB binding protein (CBP) by immunofluoresence and co-immunoprecipition assays. Finally, the expression of $\beta$-catenin and CBP in human lung adenocarcinoma specimens were analyzed by immunohistochemistry assay. Results: $\beta$-catenin knockdown inhibited cell proliferation, promoted apoptosis and suppressed cell migration in A549 and H460 cells accompanied by the decreased expression of Myc, PCNA, VEGF, CD44, MMP-9, MMP-13 and activated bax/caspase-3 pathway. Furthermore, co-immunoprecipition and immunofluoresence analyses revealed that CBP interacted with $\beta$-catenin and contributed to $\beta$-catenin-mediated lung cancer cell growth. Abolishment of their interaction by the Wnt/ $\beta$-catenin inhibitor ICG-001 remarkably suppressed cell proliferation. Immunohistochemistry assay of tissue microarrays from patients with lung cancer indicated that both CBP and $\beta$-catenin were highly expressed in tumor tissues and predicted poor prognosis in lung adenocarcinoma patients. Conclusions: Our study has provided new evidence for the role of $\beta$-catenin in promoting the growth of lung cancer cells through cooperation with $C B P$, and suggested that dual targeting of $\beta$-catenin and CBP could be a potential therapeutic strategy in lung cancer treatment.

W. Yu, L. Li and F. Zheng contributed equally to this work.

Wei Guo, Lijuan Zou

and Wuguo Deng

\author{
Dalian Medical University, Dalian, China \\ Sun Yat-sen University Cancer Center, Guangzhou, (China) \\ E-Mail wei1015@dmu.edu.cn/zoulijuan1963@sina.com/dengwg@sysucc.org.cn
}




\section{Cellular Physiology Cell Physiol Biochem 2017;44:467-478 and Biochemistry Published \begin{tabular}{l|l} 
DOI: 10.1159/000485013 & $\begin{array}{l}\text { (c) } 2017 \text { The Author(s). Published by S. Karger AG, Basel } \\
\text { www.karger.com/cpb }\end{array}$
\end{tabular}}

Yu et al.: B-Catenin Cooperates with CREB Binding Protein

\section{Introduction}

As the most common cancer type all over the world, lung cancer has very high incidences of recurrence, metastasis and mortality [1-3]. Despite the rapid development in clinical therapeutic strategies, the five-year survival rate for lung cancer is still lower than $20 \%$ [4]. Therefore, there is an urgent need to clarify the underlying precise mechanisms that drive lung carcinogenesis and development to provide insights into the discovery of novel therapeutic targets.

$\beta$-catenin, an integral structural component of cell adhesion junctions, is the key effector of canonical Wnt signaling in the nucleus [5]. It is mainly composed of three domains: the $\mathrm{N}$-terminal domain (NTD), the central region with residues 141-664 that form 12 imperfect Armadillo repeats, and the C-terminal domain (CTD) essential for the signaling activity of $\beta$-catenin [6]. The functional output of $\beta$-catenin can be affected by post-translational modifications including phosphorylation, ubiquitylation, acetylation and glycosylation [7]. Moreover, it is reported to regulate a set of genes involved in proliferation, cell self-renewal, survival, and differentiation through interactions with transcriptional coactivators. However, the precise function and molecular mechanisms of $\beta$-catenin in lung cancer progression remain unclear.

CREB binding protein (CBP) and P300 have been reported to be involved in cell growth, transformation and development [8]. Some studies showed that these transcriptional coactivators functioned as tumor-suppressors [9-11], whereas some other studies demonstrated that they were essential for the actions of many oncogenes such as AP1, c-jun and c-fos [12-14]. Whether CBP promotes apoptosis or cell proliferation appears to be context-dependent, and our study showed here that CBP expression was negatively correlated with the overall survival in lung cancer patients.

In this study, we examined the effects of $\beta$-catenin in lung cancer development by knocking down its expression in cancer cell lines. Also, we identified its interaction with CBP and their synergy in co-regulating lung cancer cell growth. Furthermore, we assessed the expression of CBP and $\beta$-catenin, their correlation and clinical significance in 80 lung adenocarcinoma patients with a median follow-up of 39 months. All the results have collectively indicated a pivotal role of the $\mathrm{CBP} / \beta$-catenin axis in transcriptional regulation in lung cancer development, and that it may serve as a new therapeutic target in advanced lung cancer.

\section{Materials and Methods}

Cell lines and cell culture

Three lung cancer cell lines, H1299, A549 and H460, as well as human lung fibroblast cell line HLF were purchased from ATCC. HLF was cultured in DMEM medium, while H1299, A549 and H460 were cultured in RPMI1640, supplemented with $10 \%$ FBS and $1 \%$ penicillin-streptomycin at $37^{\circ} \mathrm{C}$ with $5 \% \mathrm{CO}_{2}$.

MTT assay

Cell viability was determined by MTT assay. H1299, A549 and H460 cells were seeded in 96-well plates (5000 cells per well), treated with drugs or plasmids or siRNAs. $48 \mathrm{~h}$ after treatment, MTT (0.1\%) was added into each well, and incubated at $37^{\circ} \mathrm{C}$ for $4 \mathrm{~h}$. Absorbance at $492 \mathrm{~nm}$ was then measured.

Western blot

$30 \mu \mathrm{g}$ proteins were separated by $4 \%-10 \%$ SDS-PAGE, transferred to $0.45 \mu \mathrm{m}$ PVDF membranes and immunoblotted respectively with antibodies against $\beta$-catenin (CST) at 1:1000, CBP (CST) at 1:1000, c-Myc (proteintech) at 1:500, PCNA (santa cruz) at 1:500, GAPDH (proteintech) at 1:5000, Bcl-2 (proteintech) at 1:500, Bax (proteintech) at 1:500, cleaved-caspase3 (CST) at 1:1000, MMP-9 (proteintech) at 1:1000, MMP-13 (Santa Cruz) at 1:500, CD44 (proteintech) at 1:500, VEGF (proteintech) at 1:500, N-cadherin (proteintech) at 1:1000, E-cadherin (proteintech) at 1:1000, Claudin (CST) at 1:1000, and TF $\alpha$ B (abcam) at 1:2000. Protein bands were detected by ECL (Thermo) according to manufacturer's protocol. 


\section{Cellular Physiology Cell Physiol Biochem 2017;44:467-478 \begin{tabular}{l|l|l}
\hline DOI: 10.1159/000485013 & $\begin{array}{l}\text { C } 2017 \text { The Author(s). Published by S. Karger AG, Basel } \\
\text { www.karger.com/cpb }\end{array}$
\end{tabular} \\ Published online: November 15, 2017 www}

Migration assay

A549 and H460 cells were seeded in 6-well plates and grown to 70-80\% confluence. Then the cells were transfected with $\beta$-catenin siRNA for $24 \mathrm{~h}$ and scratched with a sterile $100 \mu \mathrm{l}$ pipette tip. The wound gaps were photographed at $0,24,48$ and $72 \mathrm{~h}$ respectively.

Plasmid and siRNA transfection

The siRNAs targeting $\beta$-catenin were siRNA-669: 5'-GCAGUUGUAAACUUG AUUATT-3', 5'-UAAUCAAGUUUACAACUGCTT-3'; siRNA-1930: 5'-GGACAC AGCAGCAAUUUGUTT-3', 5'-ACAAAUUGCUGCUGUGUCCTT-3'. The siRNAs targeting CBP were siRNA-2209: 5'-GAGGUCGCGUUUACAUAAATT-3', 5'-UUU AUGUAAACGCGACCUCTT-3'. Negative control siRNA: 5'-UUCUCCGAACGU GUCACGUTT-3', 5'-ACGUGACACGUUCGGAGAATT-3'. siRNAs were purchased from Shanghai GenePharma Co (Shanghai,China). Control siRNA, $\beta$-catenin or CBP specific siRNAs, lacZ control plasmid, and CBP or $\beta$-catenin overexpression plasmid were transfected into A549 and H460 cells according to the lipofectamine 3000 protocol (Invitrogen, USA).

\section{Apoptosis assay}

A549 and H460 cells transfected with $\beta$-catenin siRNA were analyzed by flow cytometry to detect apoptosis. After $48 \mathrm{~h}$ transfection, the cells were stained with Annexin V-FITC and propidium iodide (PI) according to the instruction of Annexin V-PI Apoptosis Detection kit (Keygen, Jiangsu, China).

\section{Confocal immunofluorescence}

HLF, H1299, A549 and H460 cells were seeded on chamber slides in 6-well plates. The cells were fixed with $4 \%$ paraformaldehyde for $30 \mathrm{~min}$ at room temperature and permeabilized with PBST, then blocked with $10 \%$ BSA for 30 min and incubated with antibodies against $\beta$-catenin (diluted to 1:100 with 5\% BSA, CST 8480S) and CBP (diluted to 1:100 with 5\% BSA, Santa Cruz sc-7300) overnight at $4^{\circ} \mathrm{C}$. After washing 3 times, cells were incubated with the fluorescein isothiocyanate and rhodamine-conjugaed secondary antibodies (diluted to 1:200 with 5\% BSA, CST 4408S and 4413S) for $1 \mathrm{~h}$. Then the nuclei were stained with DAPI for 5 min, washed with PBS for 5 times. The images were captured by Leica DM14000B confocal laser scanning microscope.

\section{Co-Immunoprecipitation}

The nuclear lysate was mixed with the antibodies against CBP or $\beta$-catenin and kept rotating at $4{ }^{\circ} \mathrm{C}$ for $3.5 \mathrm{~h}$. Then the protein $\mathrm{A} / \mathrm{G}$ agarose beads were added and continuously incubated at $4^{\circ} \mathrm{C}$ overnight. After washing with PBS buffer, the beads were mixed with loading buffer and boiled at $100^{\circ} \mathrm{C}$ for 5 min. After centrifugation, the proteins in the supernatant were separated by SDS-PAGE and detected by Western blot.

\section{Human tissue microarray}

The lung adenocarcinoma tissue microarrays were purchased from Outdo Biotech Company (Shanghai, China). All of the specimens from 90 lung adenocarcinoma patients (median age: 61.5 years; range from 30 to 84 years; 41 females and 49 males) with complete surgical resection were collected between July 2004 and June 2009. Among 90 patients, 10 with no clinical stages were excluded. The rest cases were arranged into two tissue array blocks with carcinoma tissues and adjacent normal tissues. The 7th edition International Union Against Cancer/American Joint Committee on Cancer TNM classification was applied to all enrolled patients [15]. The follow-up time range from 1 to 121 months after the primary operation (median follow-up time: 39 months).

\section{Immunohistochemical staining (IHC)}

The tissue array blocks with specimens were fixed with formalin, briefly incubated with xylene, rehydrated with graded ethanol solution, incubated with methyl alcohol containing $3 \%$ hydrogen peroxide and immersed in a citrate buffer for antigen retrieval. IHC staining was performed using StreptavidinPeroxidase IHC assay kit (ZSGB-bio, China). The antibodies against $\beta$-catenin (CST, dilution 1:50) and CBP (Santa Cruze, dilution 1:200) were used. Immunostaining was evaluated by two pulmonary pathologists using a blind protocol design. For each specimen, the total score of CBP and $\beta$-catenin expression was calculated as staining intensity (negative staining: 0 point; weak staining: 1 point; moderate staining: 2 point; and strong staining: 3 point) multiplied by the point of the percentage of stained cells (positive cells $\leq 25 \%$ of 
the cells: 1 point; $26 \%-50 \%$ of the cells: 2 point; $51 \%-75 \%$ of the cells: 3 point; $\geq 75 \%$ of the cells: 4 point). When the sample was scored $\geq 6$ point, we defined it as high expression, and low expression otherwise. The positive control of CBP and $\beta$-catenin were set up according to lung cancer from the proteinatlas website (Http://www.proteinatlas.org).

\section{Statistical analysis}

Analysis of variance (ANOVA) and Student's t-test were used to compare the values of the test and control samples. The association between CBP and $\beta$-catenin expression and categorical variables were evaluated by Pearson chi-squared test. Survival curves were calculated by Kaplan Meier method. The logrank test was used to analyze the overall survival (OS) time between different clinicopathological factors in lung adenocarcinoma. Univariate and multivariate analyses were performed using the Cox regression model. Data were analyzed by SPSS 2.0 software. $P<0.05$ was considered statistically significant. All experiments were done three times, and the mean values and standard deviation were calculated.

\section{Results}

\section{$\beta$-catenin knockdown inhibited the proliferation of lung cancer cells}

In order to clarify the protential role of $\beta$-catenin in lung cancer progression, we knocked down the expression of $\beta$-catenin with its specific siRNAs in human lung cancer cell lines H1299, A549 and H460. As is shown in Fig. 1A, the proliferation of all three cell lines was inhibited by $\beta$-catenin knockdown. Moreover, western blot analysis indicated that the inhibition of cell proliferation was accompanied by the reduced expression of c-myc and PCNA in A549 and H460 cells (Fig. 1B), suggesting the promotive effect of $\beta$-catenin in lung cancer cell proliferation.

Fig. 1. Knockdown of $\beta$-catenin inhibited the proliferation of lung cancer cells. (A) Cell proliferation of H1299, A549 and H460 was measured by MTT assay after $48 \mathrm{~h}$ treatment with $\beta$-catenin siRNAs. The mean and SD values were from three independent experiments, and ${ }^{*} \mathrm{P}<0.05,{ }^{* *} \mathrm{P}<0.01,{ }^{* * *} \mathrm{P}<0.0001$. (B) The expression of $\beta$-catenin, $c$ Myc and PCNA were measured by western blot after $48 \mathrm{~h}$ treatment with $\beta$-catenin siRNA.

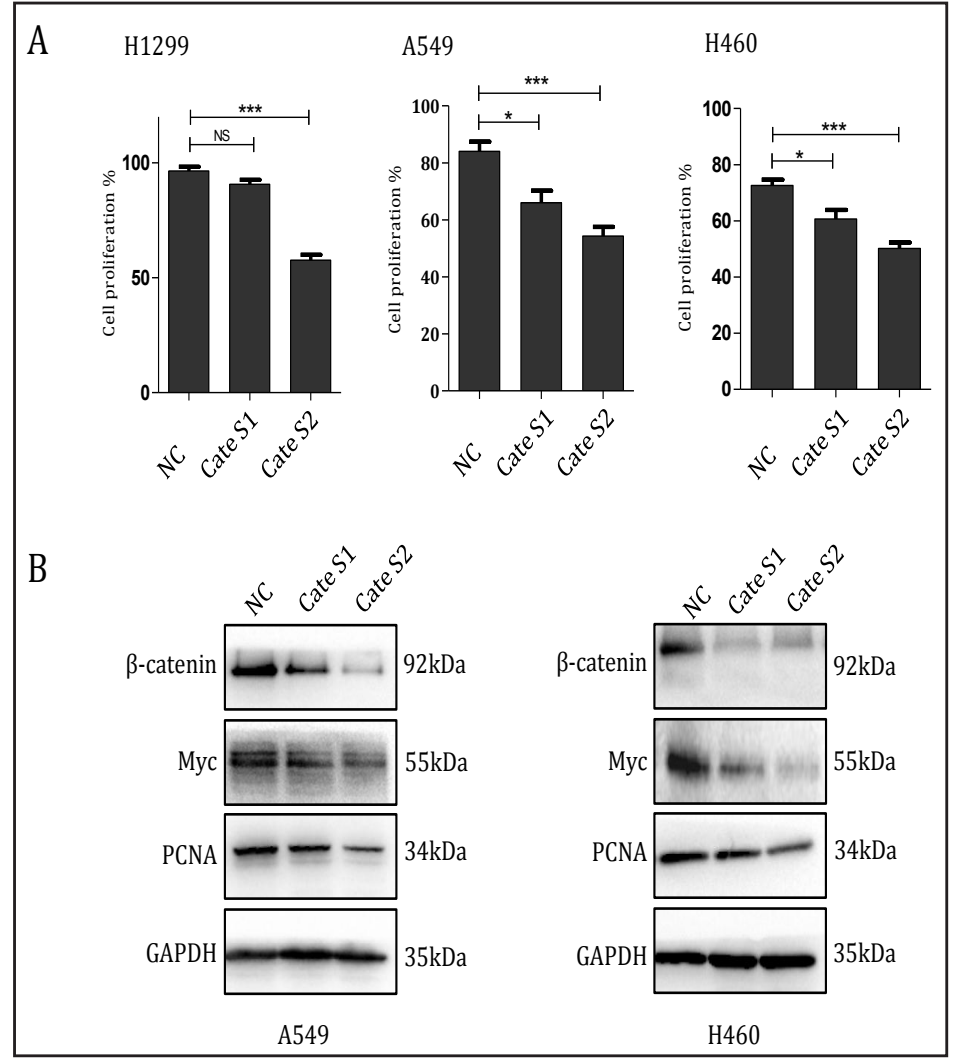




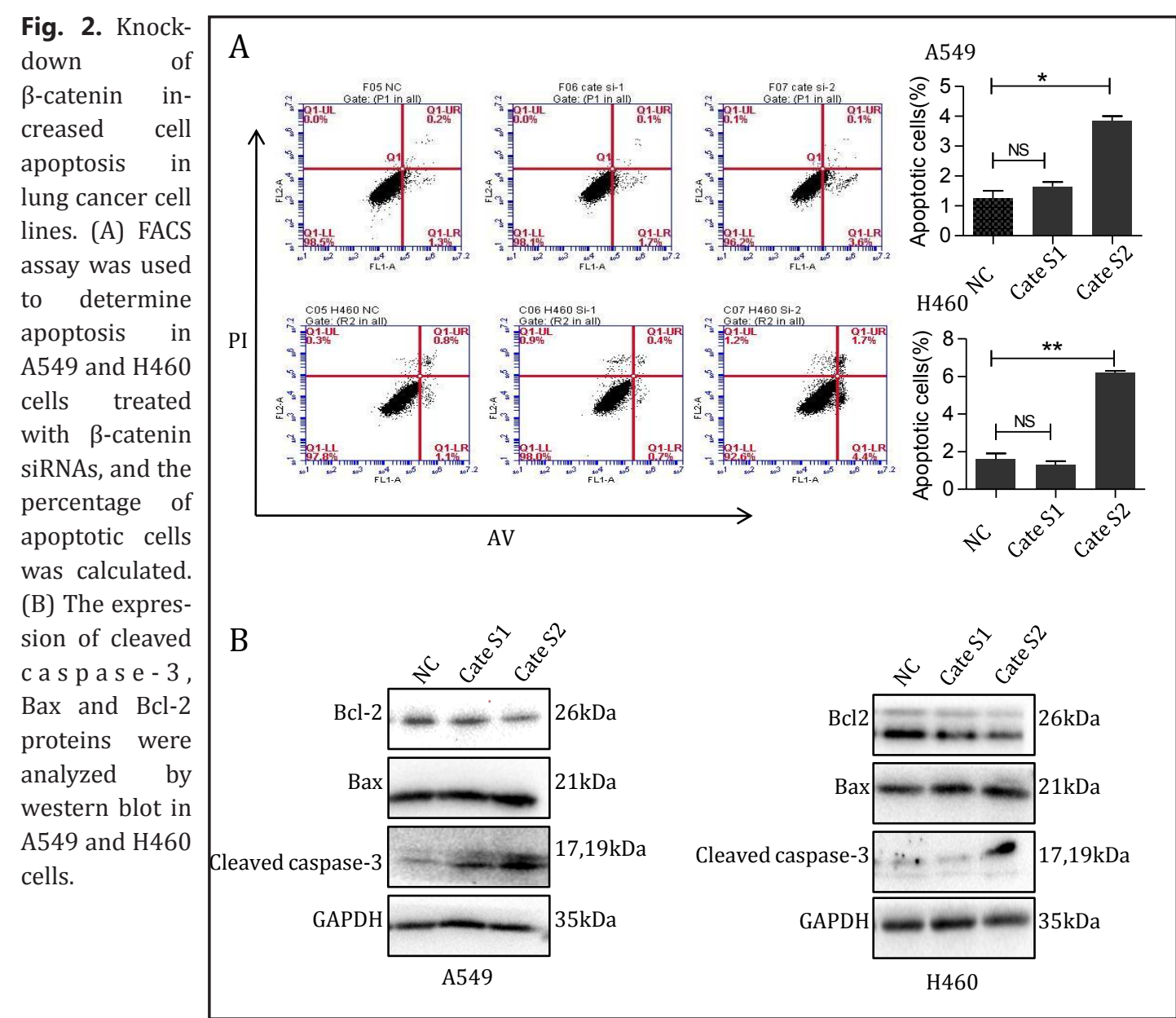

$\beta$-catenin knockdown induced apoptosis of lung cancer cells

We next assessed the effect of $\beta$-catenin in apoptosis by AV-PI assay. As is shown in Fig. $2 \mathrm{~A}$, compared to the control group, knockdown of $\beta$-catenin by siRNA- 2 resulted in more apoptosis in lung cancer cells. Also, we detected some apoptosis markers by western blot and found that knockdown of $\beta$-catenin increased the expression of cleaved caspase- 3 and Bax, but decreased the expression of Bcl-2 compared with the non-specific siRNA treatment group (Fig. 2B). The results demonstrated that the anti-proliferative effect of $\beta$-catenin knockdown in lung cancer cells was partially ediated by apoptosis induction.

\section{$\beta$-catenin knockdown inhibited lung cancer cell migration}

We further investigated the effect of $\beta$-catenin knockdown on cell migration in lung cancer cells by scratch assay. The wound space was almost fully occupied after $72 \mathrm{~h}$ in both A549 and H460 cells transfected with control siRNA. In contrast, the wound space still existed in the group treated by $\beta$-catenin siRNA (Fig. 3A and $3 \mathrm{C}$ ). Additionally, the expression of N-cadherin, claudin, CD44, VEGF, MMP-9, and MMP-13, which were usually involved in cell migration, were inhibited and E-cadherin was increased in both A549 and H460 cells transfected by $\beta$-catenin siRNA (Fig. 3B and 3D). These results suggested the involvement of $\beta$-catenin in the epithelial-mesenchymal transition (EMT) process of lung cancer development.

\section{$\beta$-catenin interacted with CBP to co-regulate lung cancer cell growth}

Based on the previous studies showing that CBP not only regulated lung carcinoma growth by activating multiple signaling pathways [16], but also interacted with $\beta$-catenin as a 
Fig. 3. Knockdown of $\beta$-catenin inhibited cell migration in lung cancer cell lines. (A, C) Cell migration assay in A549 and H460 cells following $\beta$-catenin silencing at different time points. (B, D) $\mathrm{N}$-cadherin, E-cadherin, Claudin, CD44, VEGF, M MP-9 and MMP-13 protein expression were detected by western blot in A549 and H460 cells following $\beta$-catenin silencing .

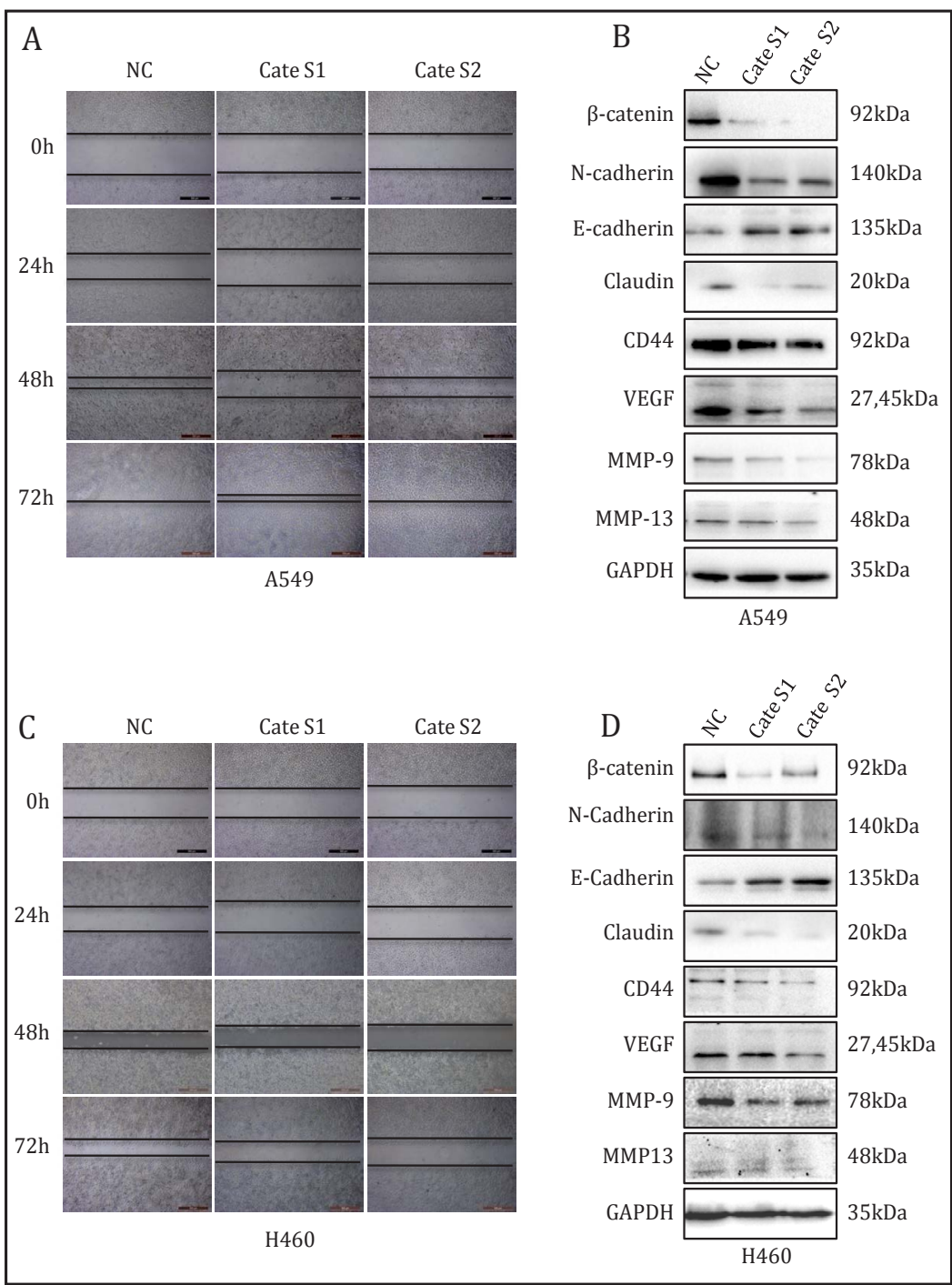

transcriptional co-activator to activate downstream target genes [17], we deduced that they might synergize to co-regulate lung tumor growth. To test this hypothesis, immunofluoresence assay was performed. As is shown in Fig. 4A, $\beta$-catenin largely co-localized with CBP in the nuclei of lung cancer cells, though it was also distributed in cell membranes and cytoplasm. To further examine their interaction, co-IP experiment was done. The nuclear extracts from lung cancer cells and normal cells were immunoprecipitated with antibodies against CBP, $\beta$-catenin or the control IgG, respectively. Then, the immunoprecipitated proteins were detected by western blot using antibodies against $\beta$-catenin or CBP. As is shown in Fig. 4B, one of them was immunoprecipitated by the antibody of the other, indicating that they interacted physically. Next, we examined the synergistic effect of CBP and $\beta$-catenin in regulating cell proliferation. A549 and $\mathrm{H} 460$ cells were transfected with CBP overexpression plasmid alone or CBP overexpression plasmid and $\beta$-catenin siRNA together. 48 hours after transfection, cell viability was detected. We found that $\beta$-catenin knockdown reversed the increased cell viability caused by CBP overexpression (Fig. 4C). Similarly, CBP knockdown or inhibition of its histone acetyltransferase (HAT) activity reversed the improved cell viability by $\beta$-catenin overexpression (Fig. 4D). The small molecule ICG-001 has been found to disrupt the interaction between CBP and $\beta$-catenin [18], and its therapeutic potential has recently been reported in pancreatic ductal adenocarcinoma (PDAC)[19]. Here, we evaluated the effect of ICG-001 on lung cancer growth, and found that ICG-001 significantly inhibited lung 


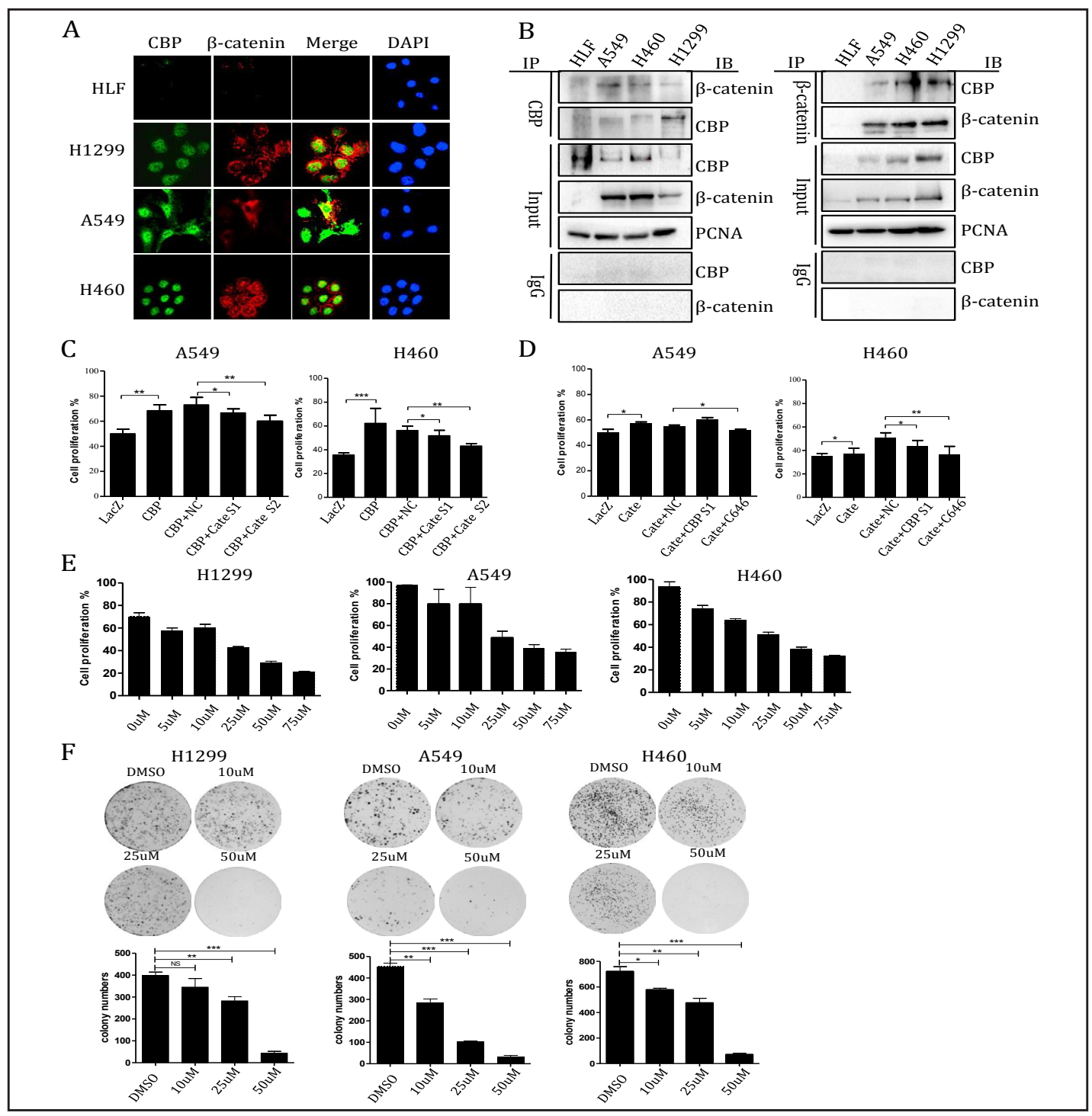

Fig. 4. $\beta$-catenin interacted with $\mathrm{CBP}$ and had a synergic effect on lung cancer cells viability. (A) Human normal lung fibroblast (HLF) and lung cancer cells (H1299, A549, H460) were grown on chamber slides for $24 \mathrm{~h}$, and the subcellular localization of $\beta$-catenin and CBP were analyzed by confocal microscope. (B) The nuclear extracted proteins from HLF, H1299, A549 and H460 cells were immunoprecipitated by CBP or $\beta$-catenin antibody, and the complexes were detected by western blot with $\beta$-catenin or CBP antibody. IgG served as a negative control. (C) Cell viability analysis in A549 and H460 cells after co-transfection with CBP plasmid and $\beta$-catenin siRNAs for $48 \mathrm{~h}$. (D) Cell viability analysis in A549 and H460 cells after cotransfection with $\beta$-catenin plasmid and CBP siRNAs for 48 h. (E) Human H1299, A549 and H460 cells were treated with ICG-001 at the indicated doses. After $48 \mathrm{~h}$ treatment, the cell viability was determined by MTT assay. (F) H1299、A549 and H460 cells were treated with ICG-001 for $48 \mathrm{~h}$ and then 5000 cells were seeded into 6-well plates, cultured at $37^{\circ} \mathrm{C}$ for one week, and the cell proliferation rate was determined by colony formation assay. Data in panel C, D and F were presented as mean \pm SD of three independent experiments with statistic significance calculated from two-tailed student's t-test $\left({ }^{*} \mathrm{P}<0.05,{ }^{* *} \mathrm{P}<0.01\right)$.

cancer cell growth in a dose-dependent manner (Fig. 4E). In addition, the colony formation ability of lung cancer cells was also significantly decreased by ICG-001 treatment (Fig. 4F), suggesting the key role of $\mathrm{CBP} / \beta$-catenin interaction in promoting lung cancer growth. 


\section{Cellular Physiology \begin{tabular}{l|l|l} 
DOI: 10.1159/000485013 & $\begin{array}{l}\text { O 2017 The Author(s). Published by S. Karger AG, Basel } \\
\text { www.karger.com/cpb }\end{array}$ \\
\cline { 1 - 2 }
\end{tabular} \\ Yu et al.: B-Catenin Cooperates with CREB Binding Protein}

Fig. 5. Both $\mathrm{CBP}$ and $\beta$-catenin were highly expressed in lung cancer cells and tissues. (A) The expression of CBP and $\beta$-catenin were detected in whole cell lysates from lung cancer cell lines and normal fibroblasts by western blot. (B) The expression of CBP and $\beta$-catenin were detected in nuclear lysates from lung cancer cell lines and normal fibroblasts by western blot. (C) The protein was extracted from five lung carcinoma tissues and normal adjacent tissues, CBP and $\beta$-catenin were detected by western blot. (D) The IHC analysis of CBP and $\beta$-catenin protein expression from human lung adenocarcinoma tissue microarrays. Case1, Case2, Case 3 are three representative cases respectively from three different patients. Tumor and adjacent tissues were from one patient for each case. (E) The protein levels of CBP and $\beta$-catenin were positively correlated in lung carcinoma tissues from 80 patients.

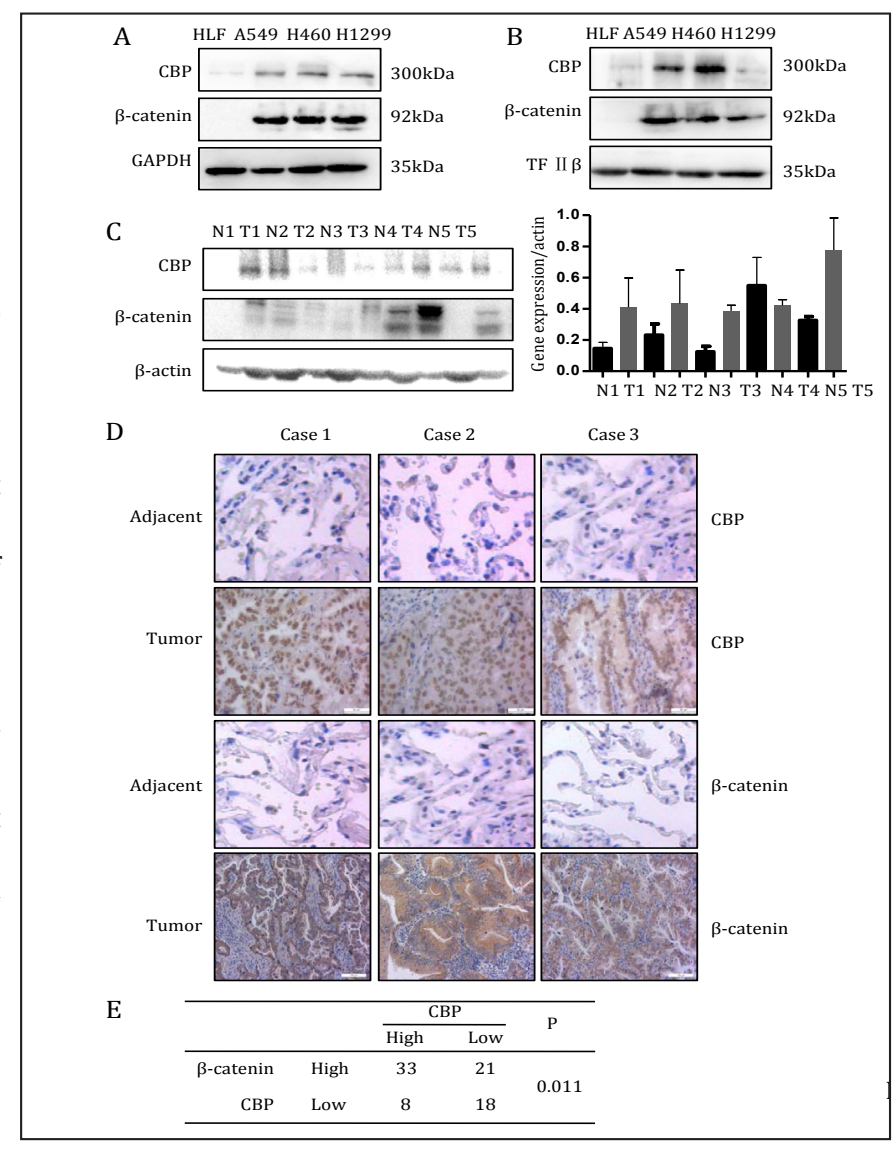

$\beta$-catenin and CBP were both highly expressed in lung cancer cells and tissues

Considering the interaction between $\beta$-catenin and CBP, we then checked the correlation of their expression in both lung cancer cells and tissues. The three lung cancer cell lines tested all had higher protein levels of $\beta$-catenin and CBP in whole cell lysates as well as nuclear lysates than normal cells (Fig. 5A and 5B). Furthermore, IHC analysis showed that both $\beta$-catenin and CBP were highly expressed in the carcinoma tissues in over $40 \%$ (33 out of 80 ) of the patient samples (Fig. 5C-5E). These results indicated that $\beta$-catenin and CBP were highly expressed in lung cancer and their expression was positively correlated.

\section{The clinical significance of $\beta$-catenin/CBP expression in lung cancer}

The IHC staining of $\beta$-catenin and CBP in 80 lung adenocarcinoma patient samples with different clinical stages (stage I $(n=32)$, stage II $(n=18)$, and stage III $(n=30))$ demonstrated that patients in more advanced stage had higher levels of $\beta$-catenin and CBP expression (Fig. 6A and 6B). Furthermore, the analysis of the clinicopathological significance showed that the expression of CBP was highly associated with lung tumor differentiation $(\mathrm{P}=0.031)$, whereas the expression of $\beta$-catenin was associated with regional lymph node involvement $(\mathrm{pN})(\mathrm{p}=0.045)$ (Fig. 6C).

Univariate analysis revealed that the overall survival (OS) rate of patients with lower CBP expression was significantly higher than the patients with higher CBP expression $(\mathrm{P}=0.045)$ (Fig. $6 \mathrm{D}$ and Table 1; the 5 -year OS rate: $51.7 \%$ vs $29.3 \%$ ). However, the OS was not significantly different between patients with high and low $\beta$-catenin expression $(\mathrm{P}=0.666)$ (Fig. 6E and Table 1). Moreover, multivariate survival analysis revealed that high CBP expression was a significant hazard ratio (HR) predictor for lung adenocarcinoma (HR=2.135, 95\% CI: 1.154-3.952, $\mathrm{P}=0.016$ ) (Table 2). 
Fig. 6. The clinical correlation analyses of CBP and $\beta$-catenin expression in 80 lung carcinoma patients. (A) $\beta$-catenin expression by IHC was classified as low or high in 80 human lung cancer tissues with different clinical stages. Percentages of $\beta$-catenin and CBP expression at different levels in each stage were depicted on the right. The representative staining results were shown on the left. Scale bars, 500 $\mu \mathrm{m}$ (50x); $100 \mu \mathrm{m}$ (400x). (B) CBP expression by IHC was classified as low or high in 80 human lung can-

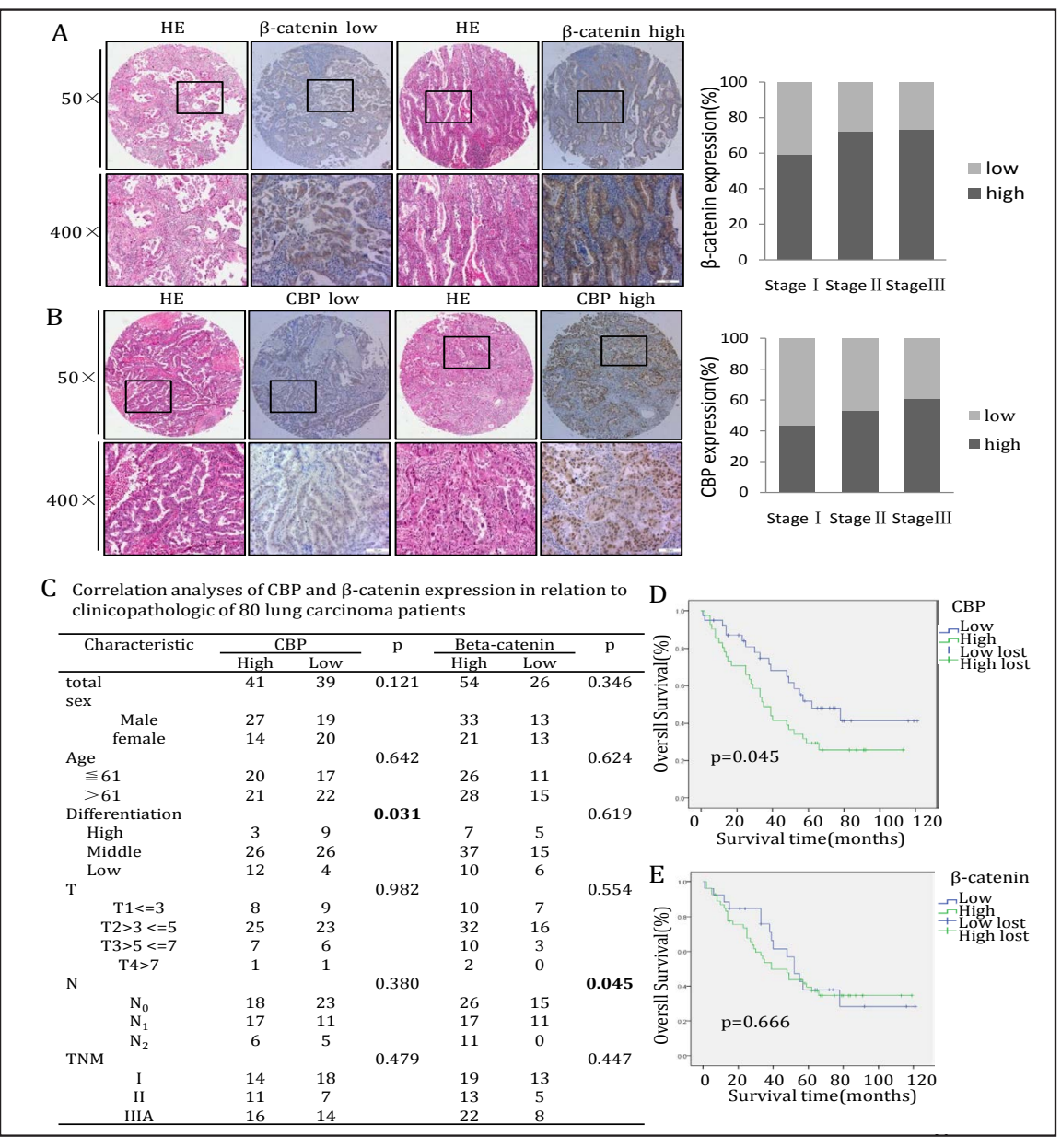
cer tissues with

different clinical stages. (C) Correlation of $\beta$-catenin and CBP expression in relation to clinicopathologic variables of 80 lung adenocarcinoma patients. (D) Overall survival of lung adenocarcinoma patients with high or low CBP expression was analyzed by Kaplan-Meier analysis. (E) Overall survival of lung adenocarcinoma patients with high or low $\beta$-catenin expression was analyzed by Kaplan-Meier analysis.

\section{Discussion}

$\beta$-catenin is short-lived in normal states [20], and its stability is regulated by Whtdependent pathway. Once it is phosphorylated by GSK3 $\beta[21]$, it is ubiquitinated for subsequent degradation by the $26 \mathrm{~S}$ proteasome [22]. Recent studies have demonstrated that the stability of $\beta$-catenin can be affected by Wnt-independent mechanisms. For instance, Siah- 1 can enhance the binding activity of Ebi to $\beta$-catenin, which subsequently promotes the degradation of $\beta$-catenin $[23,24]$. In pathological conditions, $\beta$-catenin may escape from its degradation fate by mutations that prevent it from being phosphorylated by GSK3 $\beta[25$, $26]$. In our study, we found that $\beta$-catenin was overexpressed in lung cancer cells, and its knockdown led to lung cancer cell growth inhibition and apoptosis induction. It deserves further investigation whether the aberrant expression of $\beta$-catenin was due to the mutations of its phosphorylate sites or its impaired degradation.

Some studies have shown that $\beta$-catenin can be acetylated by CBP at lysine 49 , but the unacetylatable form of $\beta$-catenin is an activator of the c-Myc gene, which suggest that acetylation of $\beta$-catenin by CBP may act negatively to regulate transcription [27]. In contrast, there are also instances showing that CBP acts positively to co-activate $\beta$-catenin-dependent 
transcription, and its acetyltransferase activity is not necessary for such activation $[28,29]$. To untangle the relationship between $\beta$-catenin and CBP in lung cancer cells, we found that CBP and $\beta$-catenin interacted with each other, and the regulation of lung cancer cell growth mediated by $\beta$-catenin was CBP-dependent. It remains to be elucidated whether CBP acetylates $\beta$-catenin in lung cancer cells, and if so, whether such acetylation has oncogenic or tumor suppressive effect.

As a specific inhibitor of $\beta$-catenin/CBP interaction, ICG-001 represses a subset of $\beta$-catenin-mediated transcription. In this study, ICG-001 was used to treat lung cancer cells to see whether disruption of $\beta$-catenin/ CBP interaction inhibited lung tumor growth. Similar to the effects of $\beta$-catenin knockdown, ICG-001 also caused significant growth suppression of lung cancer cells, which was consistent with with its reported function in Pancreateic cancer cells [18]. The IC $_{50}$ values of ICG-001 for H1299, A549 and $\mathrm{H} 460$ are $45.8 \mu \mathrm{M}, 41.4 \mu \mathrm{M}$ and $39.4 \mu \mathrm{M}$ respectively, which were similar to the study in hepatpcellular carcinoma cell lines [30]. Furthermore, ICG-001 regulated many genes altered by $\beta$-catenin knockdown, including MMP 9 and c-Myc. All these results supported that the promotion of lung tumor progression mediated by $\beta$-catenin was CBP-dependent, and the disruption of $\beta$-catenin/CBP might be a new option in targeting therapy of lung cancer.

Accumulating evidence has strongly suggested that $\beta$-catenin is a crucial factor in various processes of cancer development [31-35]. In our study, we found that $\beta$-catenin expression was associated with regional lymph node involvement but not the overall survival. Taking into account the previous studies demonstrating that $\beta$-catenin was locaized in both the cytoplasm and the nucleus [36], we speculate here that the clinical function of $\beta$-catenin is, at least in part, determined by its subcellular localization. This will be addressed in future studies with larger sample cohorts.
Table 1. The five-year overall survival on different clinicopathological factors was used Kaplan Meier and univariate analysis

\begin{tabular}{|c|c|c|}
\hline Characteristic & $5-\mathrm{OS}(\%)$ & $\mathrm{P}$ \\
\hline Age & & 0.845 \\
\hline$\leqq 61$ & 40.6 & \\
\hline$>61$ & 37.8 & \\
\hline Differentiation & & 0.225 \\
\hline High & 81.8 & \\
\hline Middle & 28.1 & \\
\hline Low & 40.6 & \\
\hline $\mathrm{T}$ & & 0.065 \\
\hline $\mathrm{T} 1$ & 63.3 & \\
\hline $\mathrm{T} 2$ & 33.0 & \\
\hline T3 & 35.2 & \\
\hline T4 & 0 & \\
\hline $\mathrm{N}$ & & $<0.001$ \\
\hline $\mathrm{N}_{0}$ & 64.0 & \\
\hline $\mathrm{N}_{1}$ & 18.4 & \\
\hline N2 & 9.1 & \\
\hline TNM & & $<0.001$ \\
\hline I & 65.3 & \\
\hline II & 43.8 & \\
\hline III & 11.0 & \\
\hline CBP & & 0.045 \\
\hline High & 29.3 & \\
\hline Low & 51.7 & \\
\hline Beta-catenin & & 0.666 \\
\hline High & 39.4 & \\
\hline Low & 37.9 & \\
\hline
\end{tabular}

Table 2. Multivariate analysis of overall survival used Cox-regression.

\begin{tabular}{lccc}
\hline Factors & HR & $95 \% \mathrm{CI}$ & $\mathrm{P}$ \\
\hline $\mathrm{N}$ & & & \\
$\mathrm{N}_{0}$ & 0.106 & $0.045-0.253$ & $<0.001$ \\
$\mathrm{~N}_{1}$ & 0.272 & $0.120-0.617$ & 0.002 \\
$\mathrm{~N}_{2}$ & 1 & & \\
TNM & & & \\
$\mathrm{I}$ & 0.557 & $0.125-2.477$ & 0.442 \\
$\mathrm{II}$ & 2.229 & $1.203-4.131$ & 0.207 \\
$\mathrm{III}$ & 1 & & \\
CBP & & & \\
$\quad$ High & 2.135 & $1.154-3.952$ & 0.016 \\
$\quad$ Low & 1 & & \\
\hline
\end{tabular}

\section{Conclusion}

In summary, our study has revealed the high expression of $\beta$-catenin in lung cancer cells and its role in lung tumorigenesis. Notably, we uncovered its interaction with CBP, and their synergy in lung cancer development. Our research has suggested a new therapeutic strategy for lung cancer treatment by targeting the $\beta$-catenin/CBP signaling axis. 


\section{Cellular Physiology Cell Physiol Biochem 2017;44:467-478 and Biochemistry Published online: November 15, $2017 \begin{aligned} & \text { DOI: 10.1159/000485013 } 2017 \text { The Author(s). Published by S. Karger AG, Basel } \\ & \text { www.karger.com/cpb }\end{aligned}$}

Yu et al.: B-Catenin Cooperates with CREB Binding Protein

\section{Acknowledgements}

This work was supported by the funds from the National Natural Science Foundation of China (81470337, 81472178); the State "973 Program" of China (2014CB542005); the Natural Science Foundation of Liaoning Province (2014023009, 2015020661); the Education Department of Liaoning Province in China (Scientific Research Projects, L2015142).

\section{Disclosure Statement}

The authors declare no conflicts of interest.

\section{References}

1 Sagae S, Kobayashi K, Nishioka Y, Sugimura M, Ishioka S, Nagata M, Terasawa K, Tokino T, Kudo R: Mutational analysis of beta-catenin gene in Japanese ovarian carcinomas: frequent mutations in endometrioid carcinomas. Jpn J Cancer Res 1999;90:510-515.

-2 Jemal A, Bray F, Center MM, Ferlay J, Ward E, Forman D: Global cancer statistics. CA Cancer J Clin 2011;61:69-90.

3 Jemal A, Siegel R, Xu J, Ward E: Cancer statistics, 2010 CA Cancer J Clin 2010;60:277-300.

-4 Molina JR, Yang P, Cassivi SD, Schild SE, Adjei AA: Non-small cell lung cancer: epidemiology, risk factors, treatment, and survivorship. Mayo Clin Proc 2008;83:584-594.

5 Tai D, Wells K, Arcaroli J, Vanderbilt C, Aisner DL, Messersmith WA, Lieu CH: Targeting the WNT Signaling Pathway in Cancer Therapeutics. Oncologist 2015;20:1189-1198.

-6 Xing Y, Takemaru K, Liu J, Berndt JD, Zheng JJ, Moon RT, Xu W: Crystal structure of a full-length beta-catenin. Structure 2008;16:478-487.

7 Valenta T, Hausmann G, Basler K: The many faces and functions of beta-catenin. EMBO J 2012;31:27142736.

8 Goodman RH, Smolik S: CBP/p300 in cell growth, transformation, and development. Genes Dev 2000;14:1553-1577.

-9 Asaduzzaman M, Constantinou S, Min H, Gallon J, Lin ML, Singh P, Raguz S, Ali S, Shousha S, Coombes RC, Lam EW, Hu Y, Yague E: Tumour suppressor EP300, a modulator of paclitaxel resistance and stemness, is downregulated in metaplastic breast cancer. Breast Cancer Res Treat 2017;163:461-474.

10 Gao Y, Geng J, Hong X, Qi J, Teng Y, Yang Y, Qu D, Chen G: Expression of p300 and CBP is associated with poor prognosis in small cell lung cancer. Int J Clin Exp Pathol 2014;7:760-767.

11 Guo W, Lu J, Dai M, Wu T, Yu Z, Wang J, Chen W, Shi D, Yu W, Xiao Y, Yi C, Tang Z, Xu T, Xiao X, Yuan Y, Liu Q, Du G, Deng W: Transcriptional coactivator CBP upregulates hTERT expression and tumor growth and predicts poor prognosis in human lung cancers. Oncotarget 2014;5:9349-9361.

12 Arias J, Alberts AS, Brindle P, Claret FX, Smeal T, Karin M, Feramisco J, Montminy M: Activation of cAMP and mitogen responsive genes relies on a common nuclear factor. Nature 1994;370:226-229.

13 Lee D, Lee B, Kim J, Kim DW, Choe J: cAMP response element-binding protein-binding protein binds to human papillomavirus E2 protein and activates E2-dependent transcription. J Biol Chem 2000;275:70457051.

14 Bannister AJ, Oehler T, Wilhelm D, Angel P, Kouzarides T: Stimulation of c-Jun activity by CBP: c-Jun residues Ser63/73 are required for CBP induced stimulation in vivo and CBP binding in vitro. Oncogene 1995;11:2509-2514.

15 Groome PA, Bolejack V, Crowley JJ, Kennedy C, Krasnik M, Sobin LH, Goldstraw P, Committee IIS, Cancer R, Biostatistics, Observers to the C, Participating I: The IASLC Lung Cancer Staging Project: validation of the proposals for revision of the T, N, and M descriptors and consequent stage groupings in the forthcoming (seventh) edition of the TNM classification of malignant tumours. J Thorac Oncol 2007;2:694-705.

16 Qin Y, Chen W, Xiao Y, Yu W, Cai X, Dai M, Xu T, Huang W, Guo W, Deng W, Wu T: RFPL3 and CBP synergistically upregulate hTERT activity and promote lung cancer growth. Oncotarget 2015;6:2713027145. 


\section{Cellular Physiology Cell Physiol Biochem 2017;44:467-478 \begin{tabular}{l|l|l|} 
DOI: 10.1159/000485013 & $\begin{array}{l}\text { O 2017 The Author(s). Published by S. Karger AG, Basel } \\
\text { www.karger.com/cpb }\end{array}$
\end{tabular}

Yu et al.: B-Catenin Cooperates with CREB Binding Protein

17 Takemaru KI, Moon RT: The transcriptional coactivator CBP interacts with beta-catenin to activate gene expression. J Cell Biol 2000;149:249-254.

-18 Emami KH, Nguyen C, Ma H, Kim DH, Jeong KW, Eguchi M, Moon RT, Teo JL, Kim HY, Moon SH, Ha JR, Kahn M: A small molecule inhibitor of beta-catenin/CREB-binding protein transcription [corrected]. Proc Natl Acad Sci U S A 2004;101:12682-12687.

19 Arensman MD, Telesca D, Lay AR, Kershaw KM, Wu N, Donahue TR, Dawson DW: The CREB-binding protein inhibitor ICG-001 suppresses pancreatic cancer growth. Mol Cancer Ther 2014;13:2303-2314.

20 Kimelman D, Xu W: beta-catenin destruction complex: insights and questions from a structural perspective. Oncogene 2006;25:7482-7491.

-21 Liu C, Li Y, Semenov M, Han C, Baeg GH, Tan Y, Zhang Z, Lin X, He X: Control of beta-catenin phosphorylation/degradation by a dual-kinase mechanism. Cell 2002;108:837-847.

-22 Xing Y, Clements WK, Kimelman D, Xu W: Crystal structure of a beta-catenin/axin complex suggests a mechanism for the beta-catenin destruction complex. Genes Dev 2003;17:2753-2764.

23 Matsuzawa SI, Reed JC: Siah-1, SIP, and Ebi collaborate in a novel pathway for beta-catenin degradation linked to p53 responses. Mol Cell 2001;7:915-926.

-24 Dimitrova YN, Li J, Lee YT, Rios-Esteves J, Friedman DB, Choi HJ, Weis WI, Wang CY, Chazin WJ: Direct ubiquitination of beta-catenin by Siah-1 and regulation by the exchange factor TBL1J Biol Chem 2010;285:13507-13516.

25 Polakis P: The many ways of Wnt in cancer. Curr Opin Genet Dev 2007;17:45-51.

-26 Lucero OM, Dawson DW, Moon RT, Chien AJ: A re-evaluation of the "oncogenic" nature of Wnt/beta-catenin signaling in melanoma and other cancers. Curr Oncol Rep 2010;12:314-318.

-27 Hecht A, Vleminckx K, Stemmler MP, van Roy F, Kemler R: The p300/CBP acetyltransferases function as transcriptional coactivators of beta-catenin in vertebrates. EMBO J 2000;19:1839-1850.

-28 Ma B, Fey M, Hottiger MO: WNT/beta-catenin signaling inhibits CBP-mediated RelA acetylation and expression of proinflammatory NF-kappaB target genes. J Cell Sci 2015;128:2430-2436.

29 Wolf D, Rodova M, Miska EA, Calvet JP, Kouzarides T: Acetylation of beta-catenin by CREB-binding protein (CBP). J Biol Chem 2002;277:25562-25567.

30 Ellerkamp V, Lieber J, Nagel C, Wenz J, Warmann SW, Fuchs J, Armeanu-Ebinger S: Pharmacological inhibition of beta-catenin in hepatoblastoma cells. Pediatr Surg Int 2013;29:141-149.

31 Mishra A, Singh V, Verma V, Pandey S, Trivedi R, Singh HP, Kumar S, Dwivedi RC, Mishra SC: Current status and clinical association of beta-catenin with juvenile nasopharyngeal angiofibroma. J Laryngol Otol 2016;130:907-913.

-32 Di Bartolomeo M, Pietrantonio F, Pellegrinelli A, Martinetti A, Mariani L, Daidone MG, Bajetta E, Pelosi G, de Braud F, Floriani I, Miceli R: Osteopontin, E-cadherin, and beta-catenin expression as prognostic biomarkers in patients with radically resected gastric cancer. Gastric Cancer 2016;19:412-420.

33 Pang H, Lu H, Song H, Meng Q, Zhao Y, Liu N, Lan F, Liu Y, Yan S, Dong X, Cai L: Prognostic values of osteopontin-c, E-cadherin and beta-catenin in breast cancer. Cancer Epidemiol 2013;37:985-992.

-34 Abd El-Rehim D, Ali MM: Aberrant expression of beta-catenin in invasive ductal breast carcinomas. J Egypt Natl Canc Inst 2009;21:185-195.

-35 Niu X, Liu S, Jia L, Chen J: Role of MiR-3619-5p in beta-Catenin-Mediated Non-Small Cell Lung Cancer Growth and Invasion. Cell Physiol Biochem 2015;37:1527-1536.

36 Wang JL, Chen ZF, Chen HM, Wang MY, Kong X, Wang YC, Sun TT, Hong J, Zou W, Xu J, Fang JY: Elf3 drives beta-catenin transactivation and associates with poor prognosis in colorectal cancer. Cell Death Dis 2014;5:e1263. 